\title{
Street Children: Implication on Mental Health and the Future of West Africa
}

\section{Davou Francis John'1, Armiya'u Aishatu Yusha'u2², Tungchama Friday Philip³, Maigari Yusufu Taru ${ }^{3}$}

${ }^{1}$ Department of Psychiatry, College of Health Sciences, University of Abuja, Abuja, Nigeria

${ }^{2}$ Department of Psychiatry, Jos University Teaching Hospital, Jos, Nigeria

${ }^{3}$ Department of Psychiatry, University of Jos, Jos, Nigeria

Email: *aarmiyau@gmail.com

How to cite this paper: John, D. F., Yusha'u, A. A., Philip, T. F., \& Taru, M. Y. (2019). Street Children: Implication on Mental Health and the Future of West Africa. Psychology, 10, 667-681. https://doi.org/10.4236/psych.2019.105041

Received: January 19, 2019

Accepted: April 7, 2019

Published: April 10, 2019

Copyright (c) 2019 by author(s) and Scientific Research Publishing Inc. This work is licensed under the Creative Commons Attribution International License (CC BY 4.0).

http://creativecommons.org/licenses/by/4.0/

\section{(c) (i) Open Access}

\begin{abstract}
Background: Street life is a common sight among children in Africa including Nigeria. Distressed, hungry and poorly groomed children can be seen roaming the streets in search for means of survival from well-wishers and passersby. Poverty, cultural practices and religious belief have been cited as being responsible for such problems. The study aimed at determining the sociodemographic factors responsible for children being on the streets. It also seeks to establish the mental health effects of children being on the streets. Two questionnaires were designed by the researchers to collect information about respondents. One hundred and seven (107) of these children were interviewed. The study revealed the predominance of male children (91.6\%), children from Islamic background (85.0\%) whose parents were involved in unskilled jobs (72.0\%). A statistically significant relationship was observed between street life and sociodemographic factors. Over four-fifth of the children have faced various forms of physical, sexual, emotional abuse with about three-quarter involved with alcohol and other drugs. In conclusion, the study revealed that poverty, low family income and large family sizes were responsible for children being on the streets.
\end{abstract}

\section{Keywords}

Street, Children, West Africa, Mental Health, Nigeria

\section{Introduction}

All over the world, especially in big cities, there is an unprecedented number of children either living or working on the streets. According to the United Nations Children's Fund (UNICEF), estimated tens of millions of children are living and 
working on the streets (UNICEF, 2006). A "street child" by a definition adopted by UNICEF and developed with Latin America in mind, is any child (girl or boy) below the age of 18 years (United Nations Convention on the Rights of the Child, 1992) for whom the streets (in the widest sense of the word, including unoccupied dwellings, wastelands etc.) have become his/her habitual abode and or source of livelihood; and who is inadequately protected, supervised or directed by responsible adults (Black, 1997).

Along the lengths of most streets in West Africa are several millions of children hawking and begging passersby for means of survival (Sule, 2002). According to Adetoro (2010), over seven and a half million children are roaming aimlessly on the streets of Nigeria. A recent report by the Universal Basic Education Commission (UBEC) put the figure at 9,961,699 (approximately 10 million) street children (Wike, 2013). A few of these children are on these streets with a parent or other family members begging or hawking, with majority unaccompanied and may sleep on the streets (Babangida, 1993). While on the streets, these children are subjected to harsh weather conditions, poor feeding habits (Zakir, Abubabkar, Lawal et al., 2014) and all forms of abuse (Gupta, 2000; Aderinto, 2000; Sethi, 2004; Salis, 1995).

In Ghana, the Catholic Action for Street Children reports indicates that the numbers of street children has increased. In 1999, it was estimated that 15,000 children were living and working on the streets of Accra, the capital of Ghana (Beauchemin, 1999); this rose to 20,000 in 2002 (Catholic Action for Street Children, 2003). These figures revealed, relate to only one of the 10 major cities in Ghana; it is therefore likely to be higher when the whole country is considered. The irony of the problem is the fact that, the children are deprived of basic education, parental love and basic healthcare with illnesses suffered taken care of by nature (Adetoro, 2010).

Several studies have shown that street children have been introduced to alcohol and drugs (Zakir, Abubabkar, Lawal et al., 2014; Gaidhane, Zahiruddin, Waghmare et al. 2008; Childline India Foundation, 2010; Benegal, Bhushan, Seshadri et al., 1998) and are at a higher risk for developing mental illness (Imasiku \& Banda, 2015; Laraqui, Caubet, Laraqui et al., 2000; Thabet, Matar, Carpintero et al., 2011). They may also become gangsters, engaging in criminal activities ranging from petty thievery (Aptekar, 1989) to armed robbery. Overzealous politicians have recruited them as merchants of war and violence during socio-political and economic disputes.

While some of these children were driven to the streets by wars and terrorism (Veale, 1992), socio-political and religious crises as well as poverty (Cortina, Sodha, Fazel et al., 2012; de Pineda, de Munoz, de Pineda et al., 1978; Rosa, de Sousa, \& Ebrahim, 1992; Ojanuga, 1990), accusation of witchcraft (de Pineda, de Munoz, de Pineda et al., 1978) is one common reason in the African continent. Some of them are supposedly under the tutelage of a "teacher-Malam" who instructs with religious teachings and is responsible for their care. Majority of these children (with some being as young as 3 years old) are most times taken 
from one part of the country or even sub-continent to another and handed over to these teachers (Sule, 2002; Babangida, 1993). However, as task relieving as it may seem to the parents of these children who are usually impoverished rural dwellers, sadly, the children are released to the streets to beg and fend for themselves. Part of their duty is to bring back all the proceeds they were able to get from the public to the teacher who decides what to do with it. Most times the teacher keeps the best part of the proceeds for his family including his children who in most cases do not also walk or work the streets (Sulaiman, 1996). It is worthy to note that as these children grow up, they lose the identity of where they came from.

This study aims to determine the sociodemographic factors responsible for children being on the streets. It also seeks to establish the mental health effects of children being on the streets.

\section{Method and Materials}

\subsection{Study Design and Location}

A cross-sectional descriptive study was carried out among 107 subjects in Jos, Plateau state North-Central Nigeria.

\subsection{Research Procedure}

Assent was received from the "Malams" who are the custodian of some of these street children. Only two Malams gave assent for their children to be interviewed. The remaining 11, declined for their children to be interviewed. In cases where these assents were denied, assessment was still made by approaching these children on the streets. This was still considered ethically acceptable as the report obtained here may serve as source of information for lifesaving interventions and the outcome is in the best interest of the subjects. These children largely were found swarming around fuel stations, eateries, motor parks, amusement and recreation sites etc. they occasionally move from house to house. Information was gathered from 107 subjects using sociodemographic questionnaire and a questionnaire developed by the researchers.

\subsection{Instruments}

\subsubsection{Sociodemographic Characteristic Questionnaire}

The sociodemographic questionnaire was used to enquire about the age, gender, state of origin, number of siblings, occupation of parents, present living condition (housing, health, school etc.). The second questionnaire developed by the researchers was used to collect data concerning other variables such as what pushed the child to the streets, substance use with special consideration to types of substance and age of onset of use, history and form of abuse suffered while on the streets, duties on the streets. Other parameters obtained using this questionnaire includes how the basic needs of the street child were met by the Malams or their parents (health, feeding, clothing, shelter, education, opportunities to visit parents etc.). 


\subsubsection{Data Collection}

Every subject was interviewed with two questionnaires. These include a sociodemographic questionnaire alongside the questionnaire developed by researchers to collect information about why subject was on the street. All questionnaires were originally in English. However, the questionnaires were all translated to Hausa through iterative back translation for subjects who could read and understand Hausa as it was a major language in the area in which the study was conducted.

\subsubsection{Data Analysis}

Data were analyzed with Statistical Package for Social Sciences (SPSS) version 20 (Statistical Package for Social Sciences). Sociodemographic variable were analyzed using simple descriptive statistics. Chi-square test was used for categorical variables. Spearman's and Pearson's correlation were used to analyze correlation between street life with substance use and physical, sexual abuse etc. Significance was put at 0.05 .

\section{Results}

One hundred and seven children aged 3 to 17 years participated in the study. Those aged 3 - 5 years and 6 - 12 years dominated the studied subjects. Children from Muslim background constituted $85.0 \%$ of the subjects compared to $15.0 \%$ from Christianity (Table 1).

More than $65 \%$ of the children have had no form of formal education while only $27.1 \%$ and $7.5 \%$ have had one form primary or secondary education respectively. None has had or was in any tertiary institution as at the time of the study (Table 1).

Most of the children's parents were involved in unskilled jobs (72.0\%); those involved in skilled jobs were $4.6 \%$ with the remaining $23.4 \%$ involved in semi-skilled jobs (Table 1).

Majority (37.4\%) of the subjects had between 7 - 9 siblings; this is followed by those with 4 - 6 (29.0\%). A little over a quarter had 1 - 3 siblings and those with 10 or more siblings made up the remaining $20.5 \%$ (Table 1 ).

The States of origin was categorized according to the geopolitical zone the children came from. Using the 6 constitutionally recognized geopolitical zones in Nigeria, those form the North-West dominated with $45.8 \%$ closely followed by the North-East with $37.3 \%$. The North-Central had $10.0 \%$ response. The least contribution to the number of children on the street was from the Southern part of the country; South-South $0.9 \%$, South-East $1.9 \%$ and South-West $4.7 \%$ (Table 1). A statistically significant relationship was found between being on the street and all sociodemographic variables as displayed in Table 1.

The study found that different age categories were involved in different forms of duties on the streets. The younger age groups $3-8$ years reported begging for alms, washing of plates in road side for stalls and hawking candies and packaged water. They made up $54.2 \%$ of the subjects. The older children $(9-15$ years 
Table 1. Sociodemographic characteristics of subjects.

\begin{tabular}{|c|c|c|c|}
\hline Parameter & Frequency & Percentage (\%) & $\begin{array}{c}\text { (Statistical relationship } \\
\text { between street life and } \\
\text { socio-demographic variable) }\end{array}$ \\
\hline \multicolumn{4}{|l|}{ Sex: } \\
\hline Male & 98 & 91.6 & $\mathrm{df}=1$ \\
\hline Female & 9 & 8.4 & $X^{2}=74.028$ \\
\hline Total & 107 & 100.0 & $P<0.000$ \\
\hline \multicolumn{4}{|l|}{ Age: } \\
\hline 3 - 5 years & 47 & 43.9 & $\mathrm{df}=2$ \\
\hline $6-12$ years & 40 & 37.4 & $\mathrm{X}^{2}=11.738$ \\
\hline $13-17$ years & 20 & 18.7 & $P<0.003$ \\
\hline Total & 107 & 100.0 & \\
\hline \multicolumn{4}{|l|}{ Religion: } \\
\hline Christianity & 16 & 15.0 & $\mathrm{df}=1$ \\
\hline Islam & 91 & 85.0 & $X^{2}=52.570$ \\
\hline Total & 107 & 100.0 & $P<0.000$ \\
\hline \multicolumn{4}{|l|}{ Formal Education: } \\
\hline None & 70 & 65.4 & \\
\hline Primary & 29 & 27.1 & $\begin{array}{c}\mathrm{dt}=2 \\
X^{2}-55758\end{array}$ \\
\hline Secondary & 9 & 7.5 & $X^{2}=55.758$ \\
\hline Tertiary & 0 & 0.0 & $P<0.000$ \\
\hline Total & 107 & 100.0 & \\
\hline \multicolumn{4}{|l|}{ Parents' Occupation: } \\
\hline Skilled & 5 & 4.6 & $\mathrm{df}=2$ \\
\hline Semi-skilled & 25 & 23.4 & $X^{2}=77.458$ \\
\hline Unskilled & 77 & 72.0 & $P<0.000$ \\
\hline Total & 107 & 100.0 & \\
\hline \multicolumn{4}{|l|}{ Number of Siblings: } \\
\hline $1-3$ & 14 & 13.1 & \\
\hline $4-6$ & 31 & 29.0 & $\mathrm{df}=3$ \\
\hline $7-9$ & 40 & 37.4 & $X^{2}=14.907$ \\
\hline$\geq 10$ & 22 & 20.5 & $P<0.002$ \\
\hline Total & 107 & 100.0 & \\
\hline \multicolumn{4}{|l|}{ State of Origin: } \\
\hline North-Central & 10 & 9.4 & \\
\hline North-East & 40 & 37.3 & \\
\hline North-West & 49 & 45.8 & $\mathrm{df}=5$ \\
\hline South-East & 2 & 1.9 & $X^{2}=105.355$ \\
\hline South-South & 1 & 0.9 & $P<0.000$ \\
\hline South-West & 5 & 4.7 & \\
\hline Total & 107 & 100.0 & \\
\hline
\end{tabular}

$=18.7 \%$ and $\geq 16$ years $=27.1 \%$ ) were involved in more sophisticated tasks such as car washing, criminal acts, bus conductors etc. Apart from Koranic education (92.5\%) and shelter (72.0\%), basic needs such as feeding, clothing, health and permission to visit their parents were largely unmet (Table 2).

With respect to alcohol and drug use, $77.6 \%$ have used one form of substance or the other with the older children more involved in using them $61.4 \%$. Only $7.2 \%$ experimented and stopped. These experimenters were mostly the female street children. ${ }^{*}$ A statistically significant relationship was found between substance use and gender, age and education as shown in Table 3. 
Table 2. Impact of street life on street children (Survival strategies).

\begin{tabular}{|c|c|c|}
\hline Parameter & Frequency & Percentage (\%) \\
\hline \multicolumn{3}{|l|}{ Duties on the streets according to age } \\
\hline 1) 3 - 8 years (begging for alms, hawking) & 58 & 54.2 \\
\hline $\begin{array}{l}\text { 2) } 9 \text { - } 15 \text { years (hawking, begging for alms, bus } \\
\text { conductors etc) }\end{array}$ & 20 & 18.7 \\
\hline $\begin{array}{l}\text { 3) } \geq 16 \text { years (bus conductors, water vendors, } \\
\text { truck pushers, car wash, thuggery) }\end{array}$ & 29 & 27.1 \\
\hline Total & 107 & 100.0 \\
\hline \multicolumn{3}{|l|}{ Meeting basic needs: } \\
\hline \multicolumn{3}{|l|}{ 1) Health: } \\
\hline Yes & 11 & 10.3 \\
\hline No & 96 & 89.7 \\
\hline Total & 107 & 100.0 \\
\hline \multicolumn{3}{|l|}{ 2) Feeding: } \\
\hline Yes & 38 & 35.5 \\
\hline No & 69 & 64.6 \\
\hline Total & 107 & 100.0 \\
\hline \multicolumn{3}{|l|}{ 3) Clothing: } \\
\hline Yes & 6 & 5.6 \\
\hline No & 101 & 94.4 \\
\hline Total & 107 & 100.0 \\
\hline \multicolumn{3}{|l|}{ 4) Shelter: } \\
\hline Yes & 77 & 72.0 \\
\hline No & 30 & 28.0 \\
\hline Total & 107 & 100.0 \\
\hline \multicolumn{3}{|l|}{ 5) Education: } \\
\hline Yes (Quranic) & 99 & 92.5 \\
\hline No & 8 & 7.6 \\
\hline Total & 107 & 100.0 \\
\hline \multicolumn{3}{|l|}{ 6) Visiting parents: } \\
\hline Yes & 2 & 1.9 \\
\hline No & 105 & 98.1 \\
\hline Total & 107 & 100.0 \\
\hline
\end{tabular}

Table 3. Substance use and its relationship with street life, and sociodemographic variables.

\begin{tabular}{|c|c|c|c|}
\hline \multicolumn{4}{|l|}{$\begin{array}{l}\text { History of use of substances (alcohol, } \\
\text { tramadol, cannabis, benzhexol, solvents, } \\
\text { codeine, suku dye etc.) }\end{array}$} \\
\hline Yes & & 83 & 77.6 \\
\hline No & & 24 & 22.4 \\
\hline Total & & 107 & 100.0 \\
\hline \multicolumn{4}{|l|}{ Age at onset of substance abuse: } \\
\hline 1) Experimented and stopped & & 7 & 7.2 \\
\hline 2) 3 - 5 years & & 7 & 8.4 \\
\hline 3) 6 - 12 years & & 19 & 23.0 \\
\hline 4) 13 - 17 years & & 51 & 61.4 \\
\hline Total & & 83 & 100.0 \\
\hline $\begin{array}{c}\text { SUBSTANCE } \\
\text { Yes }\end{array}$ & $\begin{array}{l}\text { USE } \\
\text { No }\end{array}$ & Frequency & Percentage Significance \\
\hline
\end{tabular}




\section{Continued}

\begin{tabular}{|c|c|c|c|c|}
\hline \multicolumn{5}{|l|}{ Gender: } \\
\hline Males & 76 & 22 & 98 & $\mathrm{df}=1$ \\
\hline Females & 7 & 2 & 9 & $X^{2}=0.675$ \\
\hline Total & 83 & 44 & 107 & $P=0.000^{*}$ \\
\hline \multicolumn{5}{|l|}{ Age (years) } \\
\hline $3-5$ & 29 & 16 & 45 & \multirow{4}{*}{$\begin{array}{c}\mathrm{df}=2 \\
\mathrm{X}^{2}=8.609 \\
P<0.014^{\star}\end{array}$} \\
\hline $6-12$ & 36 & 7 & 43 & \\
\hline $13-17$ & 18 & 1 & 19 & \\
\hline Total & 83 & 24 & 107 & \\
\hline \multicolumn{5}{|l|}{ Religion: } \\
\hline Christianity & 10 & 6 & 16 & $\mathrm{df}=1$ \\
\hline Islam & 73 & 18 & 91 & $X^{2}=2.456$ \\
\hline Total & 83 & 24 & 107 & $\mathrm{P}=0.110$ \\
\hline \multicolumn{5}{|l|}{ Formal education: } \\
\hline None & 48 & 22 & 70 & \multirow{4}{*}{$\begin{array}{c}\mathrm{df}=2 \\
X^{2}=9.593 \\
P<0.008^{\star}\end{array}$} \\
\hline Primary & 27 & 2 & 29 & \\
\hline Secondary & 8 & 0 & 8 & \\
\hline Total & 83 & 24 & 107 & \\
\hline \multicolumn{5}{|l|}{ Occupation of parents: } \\
\hline Skilled & 4 & 1 & 5 & \multirow{4}{*}{$\begin{array}{c}\mathrm{df}=2 \\
X^{2}=0.583 \\
P=0.747\end{array}$} \\
\hline Semi-skilled & 18 & 7 & 25 & \\
\hline Unskilled & 61 & 16 & 77 & \\
\hline Total & 83 & 24 & 107 & \\
\hline \multicolumn{5}{|l|}{ Number of siblings: } \\
\hline $1-3$ & 10 & 4 & 14 & \\
\hline $4-6$ & 26 & 4 & 30 & $\mathrm{df}=3$ \\
\hline $7-9$ & 33 & 8 & 41 & $X^{2}=4.386$ \\
\hline$\geq 10$ & 14 & 8 & 22 & $P=0.223$ \\
\hline Total & 83 & 24 & 107 & \\
\hline \multicolumn{5}{|l|}{ State of origin: } \\
\hline North-Central & 8 & 2 & 10 & \\
\hline North-East & 31 & 9 & 40 & \\
\hline North-West & 33 & 12 & 45 & $\mathrm{df}=5$ \\
\hline South-East & 5 & 1 & 6 & $X^{2}=2.348$ \\
\hline South-South & 1 & 0 & 1 & $P=0.799$ \\
\hline South-West & 5 & 0 & 5 & \\
\hline Total & 83 & 24 & 107 & \\
\hline
\end{tabular}

The result revealed an $82.2 \%$ abuse rate, physical abuse $70.5 \%$ and emotional abuse (11.3\%) were experienced more than sexual and neglect (9.1\% each). ${ }^{\star} \mathrm{A}$ statistically significant relationship was found between number of siblings and abuse (Table 4).

\section{Discussion}

This study has shown that street children are an endangered part of the society and an identifiable hindrance for future growth and development of the West African Sub-region.

The current study showed that the majority of children found on the streets were males. This concurred with studies conducted by Hatlǿy and Huser (2005) in Bamako, Mali and Lusk in Juarez, Mexico (1989) in which male children 
Table 4. Forms of abuse (physical, sexual, emotional and neglect) and its relationship with street life, and sociodemographic variables.

\begin{tabular}{|c|c|c|c|c|}
\hline \multicolumn{5}{|l|}{ History of abuse } \\
\hline Yes & & \multicolumn{2}{|c|}{88} & 82.2 \\
\hline No & & \multicolumn{2}{|c|}{19} & 17.8 \\
\hline Total & & \multicolumn{2}{|c|}{107} & 100.0 \\
\hline \multicolumn{5}{|l|}{ Forms of abuse: } \\
\hline 1) Physical & & \multicolumn{2}{|c|}{62} & 70.5 \\
\hline 2) Sexual & & \multicolumn{2}{|c|}{8} & 9.1 \\
\hline 3) Emotional & & \multicolumn{2}{|c|}{10} & 11.3 \\
\hline 4) Neglect & & \multicolumn{2}{|c|}{8} & 9.1 \\
\hline 5) Total & & \multicolumn{2}{|c|}{88} & 100.0 \\
\hline Parameter & $\begin{array}{c}\text { HISTORY OF } \\
\text { Yes }\end{array}$ & $\begin{array}{l}\text { ABUSE } \\
\text { No }\end{array}$ & Frequency Percentage & Significance \\
\hline \multicolumn{5}{|l|}{ Gender: } \\
\hline Males & 79 & 19 & 98 & $\mathrm{df}=1$ \\
\hline Females & 9 & 0 & 9 & $X^{2}=2.122$ \\
\hline Total & 88 & 19 & 107 & $P=0.159$ (Fisher's) \\
\hline \multicolumn{5}{|l|}{ Age (years) } \\
\hline $3-5$ & 35 & 10 & 45 & \multirow{4}{*}{$\begin{array}{c}\mathrm{df}=2 \\
X^{2}=1.862 \\
P=0.394\end{array}$} \\
\hline $6-12$ & 38 & 5 & 43 & \\
\hline $13-17$ & 15 & 4 & 19 & \\
\hline Total & 88 & 19 & 107 & \\
\hline \multicolumn{5}{|l|}{ Religion: } \\
\hline Christianity & 13 & 3 & 16 & \multirow{3}{*}{$\begin{array}{c}\mathrm{df}=1 \\
X^{2}=0.013 \\
P=0.574 \text { (Fisher's) }\end{array}$} \\
\hline Islam & 75 & 16 & 91 & \\
\hline Total & 88 & 19 & 107 & \\
\hline Formal education: & & & & \\
\hline None & 55 & 15 & 70 & \\
\hline Primary & 27 & 2 & 29 & $X^{2}=3.276$ \\
\hline Secondary & 6 & 2 & 8 & $\begin{aligned} X^{2} & =3.276 \\
P & =0.194\end{aligned}$ \\
\hline Total & 88 & 19 & 107 & $P=0.194$ \\
\hline Occupation of parent & & & & \\
\hline Skilled & 4 & 1 & 5 & \\
\hline Semi-skilled & 17 & 8 & 25 & $\begin{array}{c}\mathrm{dt}=2 \\
X^{2}=3276\end{array}$ \\
\hline Unskilled & 67 & 10 & 77 & $\begin{array}{c}X^{2}=3.276 \\
P=0.096\end{array}$ \\
\hline Total & 88 & 19 & 107 & $P=0.090$ \\
\hline Number of siblings: & & & & \\
\hline $1-3$ & 12 & 2 & 14 & \\
\hline $4-6$ & 20 & 10 & 30 & $\mathrm{df}=3$ \\
\hline $7-9$ & 39 & 2 & 41 & $X^{2}=10.128$ \\
\hline$\geq 10$ & 17 & 5 & 22 & $P=0.018^{\star}$ \\
\hline Total & 88 & 19 & 107 & \\
\hline State of origin: & & & & \\
\hline North-Central & 7 & 3 & 10 & \\
\hline North-East & 34 & 6 & 40 & \\
\hline North-West & 36 & 9 & 45 & $\mathrm{df}=5$ \\
\hline South-East & 6 & 0 & 6 & $X^{2}=2.918$ \\
\hline South-South & 1 & 0 & 1 & $P=0.713$ \\
\hline South-West & 4 & 1 & 5 & \\
\hline Total & 88 & 19 & 107 & \\
\hline
\end{tabular}

were more than the females on the streets. For an unknown reason, the Authors (Hatlǿy \& Huser, 2005) found predominance of female street children in Accra 
in the same study. Connolly (1990) also documented male child dominance on the streets in some Capitals of South American Countries. Other studies in many Countries continually found male street child population for instance, Muntingh et al. (2005) found $85 \%$ of street children in Zambia to be males, Cheng \& Lam (2010) in Shanghai found 90\% male dominance and Grundling et al. (2004) reported $85 \%$ all street children to be males. The most common claim for finding fewer girls in the streets has been that majority of them become prostitutes or are taken off the streets to assist in household chores for stipends (Agnelli, 1986; UNICEF, 1986; Nixon, 1991; Archaya, 1992). Another reason is the fact that most of the female street children were often accompanied by their mothers who refused to allow them to be interviewed.

Younger children were found to constitute about half the children on the streets. Children as young as 3 years were also sent to the streets to fend for themselves. Studies by Sule et al. (2002) and Babangida et al. (1993) also reported similar outcome in their different studies on street children and the Almajiri educational system in Nigeria. These youngsters are sent to the streets because it is believed to be part of the Almajiri educational system and a training that will make them to become more responsible at an earlier age.

The study revealed that children from the North-West and North-Eastern parts of the country (where the Hausa and Fulani population are dominant) with Islamic background were more on the streets than those from other parts of the Country. This was a similar finding to those of previous studies (Babangida, 1993; Zakir, Abubabkar, Lawal et al., 2014; Abdulqadir, 2003) in Nigeria. This can also be adduced from the fact that this street life is part of the Almajiri educational system which is largely practiced in Islam.

In our study, apart from the Quranic education which is compulsory for every street child (Abdulqadir, 2003), we found that about two-third of these street children had no formal education. The deceitful nature of the stipends they get from empathizing passersby and the higher level of poverty are usually responsible for keeping these children on the streets instead of schools. The highest level of educational attainment by a larger percentage of these children is primary education. Higher degree of lack of formal education has been reported by similar studies (Nezar \& Abdulbahgi, 2015; Abdul, 1992).

About three-quarters of these children's parents were found to be in the unskilled occupational category with majority of them having 7 - 9 children (excluding wife/wives) to meet their basic needs (Table 1). This alarming finding is definitely a significant contributor to increasing poverty and the hardships faced by these families. The above finding thus, serves as motivation that drives these children and also keeps them on the streets. Studies by Nezar and Abdulbahgi (2015), Ojanuga (1990), Zakir et al. (2014), have all reported the same finding.

A significant statistical relationship between street life and sociodemographic variable was observed in the current study (Table 1). This result indicates that sociodemographic variables play a significant role in driving and also sustaining 
street life. Significant difference in gender (where males dominates) is definitely responsible for the observed statistical relationship. Cultural and religious factor in West Africa which requires that male children must be taught to raise support and be responsible for meeting certain family needs is an important street life driver and sustainer.

Poor educational attainment, parental involvement in unskilled jobs, high parity and lack of genuine effort to address poverty and its associated factors further reinforce street life in children. Poverty (Aderinto, 2000; Aptekar, 1989; Hatlǿy \& Huser, 2005) has also been reported to be the major decisive factor for street children.

The activities engaged in by these children vary with age. According to our findings, the children tend to abandon one duty for another the older they become. The younger ones were involved in begging for alms, food, clothing as well as trading in candies. Older children were found to engage in car washing, shoe shining, bus conductors, and other forms of criminal acts like pick pocketing and thuggery. Adetoro (2010), Babangida (1993), Satyarthi (1989) and Valentina (2000) all made the same observations in their different studies on street children in different Countries.

Many of the studied street children reported using substances while on the streets with some starting to use at a much tender age. These they said help them function without getting tired. The older children made up $61.4 \%$ of this number. The commonly used substances include cannabis, alcohol, codeine, tramadol, solvents, cigarette, sedatives like diazepam and rohypnol etc. A local substance called suku dye is also in high demand. This finding concurred with findings by other authors on the same subject concerning the initiation and continued use of substances by street children. In his study in Dhaka, Bangladesh, Abdul (2014) reported that some of the street children volunteered interesting information about their pattern of substance use, he found out that use of substances is basically functional "Street children get used to certain substances to keep themselves awake for work or being intoxicated, to get to sleep, they may use other forms of drugs to achieve that". Several other studies on use of substances by street children have been done (Zakir, Abubakar, Lawal et al., 2014; Gaidhane, Zahiruddin, Waghmare et al., 2008; Childline India Foundation, 2010). Our study showed that most of those who experimented were the female street children. Report of substance abuse or dependence was not found in them.

Child abuse is a common practice in Africa even among those who are living with their parents. Studies such as those conducted by Adetoro (2010), Babangida (1993), Zakir et al. (2014), Gupta (2000), Aderinto (2000) and Sethi (2004) all cited abuse as one of the problems faced by street children. Some of the abuses were cited to be perpetrated by the law enforcement agencies in the form of illegal arrests and detentions. These findings were in keeping with what we found in this present study as shown in Table 2. Physical abuse was more directed to these children in most cases followed by emotional abuse. 
Apart from Quranic education (72.0\%) and shelter (92.5\%), other basic needs such as healthcare, clothing, feeding and opportunity to visit parents (for those from other States or Countries) were largely neglected. This finding concurred with studied carried out on similar subject (Sule, 2002; Adetoro, 2010; Babangida, 1993).

We explored the statistical relationship between sociodemographic variables, street life and substance use, only education was statistically significant $(p<$ 0.008). This is not surprising as ignorance is key to vices that may be harmful. Lack of knowledge of the dangers of using substances has been a common denominator for its abuse (Adetoro, 2010).

The number of siblings was found to be the only independent sociodemographic factor $(p<0.018)$ for abuse of street children (see Table 4$)$. Large family size, low income in the face of poverty is adjudged to be largely responsible for deprivation of basic needs and the motivation for sending the child to streets to help raise more income for the family (Commonwealth Report, 1995).

\subsection{Factors that Predispose Precipitate or Maintain Mental Health Problems Faced by Street Children}

Life on the streets has been associated with suffering, social vices and abuse. Substantial evidence have consistently linked early onset of substance use to mental and neurological disorders (Dembo et al., 1991; Hansell \& White, 1991; Shedler \& Block, 1990; SAMHSA, 1996). This study revealed early onset of substance use among these children and therefore exposing them to the above risk.

Apart from substance use, difficult childhood experience as exemplified by the life of a child who has to fend for himself on the street is also a documented predisposition to future mental health problems. Parental deprivation, physical, emotional and other forms of abuse, hunger and disease all combine to place street children at risk.

\subsection{Implication of Growing Number of Street Children for West Africa}

West Africa is witnessing population explosion due to poor birth control and other cultural factors. With little or no social facilities in the rural areas and increasing poverty due to unemployment, there is massive rural-urban drift of young children to the cities to have a bite of better life perceived to be present in the cities. This will ultimately result in more street children in most Countries of the region. With over $70.0 \%$ of the population unable to access mental health services, it only means that in the near future, the most viable part of the Sub-Continent is in danger.

\section{Conclusion}

The result from this study showed that children in Africa are endangered and facing dire psychosocial circumstances. The study also revealed that poverty, low family income and large family sizes were responsible for children being on the 
streets. It has been consistently shown that use of psychoactive substances at an earlier age just as is facing abuse predisposes to the development of mental illness; our study has shown that these children used psychoactive substances at an earlier age. This means that in the near future, the prevalence of substance related psychiatric disorders will increase significantly beyond what is recorded presently. Government must be proactive in providing all that is needed to take them off the streets to improve their quality of life.

\section{Recommendation}

Regional Heads of government in West Africa work to address the problems of street children.

Rural infrastructural development along with quality education and poverty eradication must be given due priority.

Training of more mental health personnel to help educate and offer community treatment for those involved with drugs.

\section{Acknowledgements}

We acknowledge the contributions made to this study by the children who responded to our questions and to the two "Malams" who ascent for children under their care to respond to our interview.

\section{Conflicts of Interest}

No conflict of interest to declare.

\section{References}

Abdul, A. (1992). The Problem of Street Children in Cairo and Giza. In Second Scientific Conference in Social Work. Cairo: Helwan University. (In Arabic)

Abdul, H. (2014). Problems Faced by the Street Children: A Study on Some Selected Places in Dhaka City, Bangladesh. International Journal of Scientific and Technology Research, 10, 45-56.

Abdulqadir, I. A. (2003). The Almajiri System of Education in Nigeria Today. A Paper Presented at the $21^{\text {st }}$ Convocation Ceremony of Bayero University Kano. http://www.gamji.com/article5000/NEWS5956.htm

Aderinto, A. A. (2000). Social Correlates and Coping Measures of Street Children: A Comparative Study of Street and Non-Street Children in South-Western Nigeria. Child Abuse and Neglect, 43, 1199-1213. https://doi.org/10.1016/S0145-2134(00)00172-1

Adetoro, R. (2010). The Almajiri Syndrome as a Potentials Threat to Nigeria National Security: The Role of Social Studies Education. Nigeria Journal of Social Studies, 13, $141-150$.

Agnelli, S. (1986). Street Children: A Growing Urban Tragedy. London: Weidenfeld \& Nicholson.

Aptekar, L. (1989). Picaresque Tragedies: The "Abandoned" Children in Colombia. Phenomenology and Pedagogy, 7, 79-92.

Archaya, F. (1992). Time Use Data and the Living Standards Measurement Study. Washington DC: Development Research Department, World Bank, LEMS Working Papers 
No. 18.

Babangida, I. (1993). Comparative Studies between Traditional Quranic Schools and Modern Quranic Schools in Katsina State. Zaria: Department of Islamic Education Ahmadu Bello University.

Beauchemin, E. (1999). The Exodus-The Growing Migration of Children from Ghana's Rural Areas to the Urban Centres. Catholic Action for Street Children and United Nations International and Children's Educational Fund.

Benegal, V., Bhushan, K., Seshadri, S., \& Karott, M. (1998). Drug Abuse among Street Children in Bangalore. Bangalore: National Institute of Mental Health and Neurosciences, Bangalore Forum for Street and Working Children.

Black, M. (1997). Street and Working Children: Global Seminar Report. UNICEF Innocenti Center.

Catholic Action for Street Children (2003). The State of Street Children in Ghana. http://www.casghana.com/street_publication.php

Cheng, F., \& Lam, D. (2010). How Is Street Life? An Examination of the Subjective Wellbeing of Street Children in China. International Social Work, 53, 353-365. https://doi.org/10.1177/0020872809359863

Childline India Foundation (2010). Drug Abuse among Children. http://www.childlineindia.org.in/index.htm

(1995). Commonwealth Report of the Second Commonwealth NGO Forum. Wellington.

Connolly, M. (1990). Adrift in the City: A Comparative Study of Street Children in Bogota, Colombia and Guatemala City. In N. Boxil (Ed.), Homeless Children: The Waiters and the Watchers (pp. 129-149). New York: Haworth Press.

Cortina, M. A., Sodha, A., Fazel, M., \& Ramchandani, P. G. (2012). Prevalence of Child Mental Health Problems in Sub-Saharan Africa: A Systematic Review. Archives of Pediatrics and Adolescent Medicine, 166, 276-281. https://doi.org/10.1001/archpediatrics.2011.592

Dembo, R., Williams, L., Schmeidler, J., Wish, E. D., Getreu, A., \& Berry, E. (1991). Juvenile Crime and Drug Abuse: A Prospective Study of High Risk Youth. Journal of Addictive Diseases, 11, 5-31. https://doi.org/10.1300/J069v11n02_02

de Pineda, V. E., de Munoz, P., de Pineda, Y., Echeverry, \& Aries, J. (1978). The Gamins; Social Home and Family. Bogota: Instituto Colombiano de Bienestar Familiar.

Gaidhane, A. M., Zahiruddin, Q. S., Waghmare, L., Shanbhag, S., Zodpey, S., \& Joharapurkar, S. R. (2008). Substance Abuse among Street Children in Mumbai. Vulnerable Children and Youth Studies, 3, 42-51. https://doi.org/10.1080/17450120701843166

Grundling, J. P., de Jager, J. W., \& de Fourie, L. W. (2004). Managing the Phenomenon of Street Children in an African Developing Country. Ministry of Women's Affairs and Child Welfare.

Gupta, D. (2000). Baseline Survey of Street Children of Dhaka City: A Report (p. 1). Dhaka: World Vision/DSL.

Hansell, S., \& White, H. R. (1991). Adolescent Drug Use, Psychological Distress, and Physical Symptoms. Journal of Health and Social Behavior, 32, 288-301. https://doi.org/10.2307/2136809

Hatlóy, A., \& Huser, A. (2005). Identification of Street Children: Characteristics of Street Children in Bamako and Accra. Fafo-Report 472, Oslo: Fafo.

Imasiku, M. L., \& Banda, S. (2015). Mental Health Problems of Street Children in Residential Care in Zambia: Special Focus on Prediction of Psychiatric Conditions in Street 
Children. Journal of Clinical Medicine and Research, 7, 1-6.

Laraqui, C. H., Caubet, A., Laraqui, O., Belamallem, I., Harourate, K., Curtes, J. P., \& Veger, C. (2000). Child Labour in the Artisan Sector of Morocco: Determinants and Health Effects. Sante Publique, 12, 31-43. (In French)

Lusk, M. (1989). Street Children Programs in Latin America. Journal of Sociology and Social Welfare, 16, 55-77.

Muntingh, L., Elem, D., \& Moen, L. (2005). Report on Survey and Analysis of the Situation of Street Children in Zambia. Zambia Ministry of Community Development and Social Services and Zambia Ministry of Sports and Youths and Child Development.

Nezar, I. T., \& Abdulbahgi, A. (2015). Mental Illness among Children Working on the Streets Compared with School Children in Duhok. Psychology, 6, 1421-1426.

Nixon, D. A. (1991). Street Is Not a Home (pp. 30-33). Rotarian.

Ojanuga, D. (1990). Kaduna Beggar Children: A Study of Child Abuse and Neglect in Northern Nigeria. Child Welfare, 69, 371-380.

Rosa, C. S., de Sousa, R., \& Ebrahim, G. (1992). The Street Children of Recife: A Study of Their Background. Journal of Applied Pediatrics, 38, 34-40.

Salis, T. (1995). Impact of Islamic Education in Kano Metropolitan Nursery School on Muslim Children. Zaria: Department of Islamic Education Ahmadu Bello University.

Satyarthi, K. (1989). Child Bonded Labor in South Asia: An Overview. Into That Heaven of Freedom (pp. 84-87)? Report on South Asia Seminar on Child Servitude.

Sethi, G. R. (2004). Street Children: A Window to the Reality. Indian Pediatrics, 41, 219-220.

Shedler, J., \& Block, J. (1990). Treatment of Adolescents with Substance Use Disorders, Adolescent Drug Use and Psychological Health. American Psychologist, 5, 612-630. https://doi.org/10.1037/0003-066X.45.5.612

Statistical Package for Social Sciences (SPSS 20.0). Chicago.

Substance Abuse and Mental Health Services Administration SAMHSA (1996). National Household Survey on Drug Abuse: Population Estimates 1995. Rockville, MD: SAMHSA, Office of Applied Studies.

Sulaiman, J. (1996). Health Impact of Street Beggars. Journal of Medicinal Food, 10, 70-87.

Sule, A. K. (2002). The Almajiri Phenomenon Study of the Youth in Traditional Quran Scholarship in Northern Nigeria. Seminar Presentation Notes for the Almajiri Initiatives, UDU Sokoto, Nigeria. The Humanities Journal, 1, 27-47.

Thabet, A. A., Matar, S., Carpintero, A., Bankart, J., \& Vostanis, P. (2011). Mental Health Problems among Labour Children in the Gaza Strip. Child: Care, Health \& Development, 37, 89-95. https://doi.org/10.1111/j.1365-2214.2010.01122.x

UNICEF (2006). The State of the World's Children, Excluded and Invisible.

United Nations Convention on the Rights of the Child (1992). https://www.childrensright.ie > un-convention

UNICEF (1986). Children in Especially Difficult Circumstances: Supporting Annex, Exploitation of Working and Street Children. New York: United Nations Children's Fund.

Valentina, F. (2000). Challenges in Combating Child Labor from an Occupational Health Perspective. Asian Pacific Newsletter, 2, 28-31.

Veale, A. (1992). Inwards a Conceptualization of Street Children: The Case from Sudan 
and Ireland. Yoaire Development Review, 107-128.

Wike, E. N. (2013). Improving Access and Inclusive Education in Nigeria: Update on the Almajiri Education Program.

Zakir, A., Abubakar, U., Lawal, U. S., Imrana, H., Habibu, I. T., Hassan, I. H., \& Harande, M. M. (2014). The Practice of Almajiri: Prospects and Socio-Medical Challenges in Northern Part of Nigeria. Journal of African Studies and Development, 6, 128-131.

https://doi.org/10.5897/JASD2014.0273 